\title{
KEMAMPUAN ACARA BUDAYA MENGHASILKAN KUNJUNGAN DESTINASI: STUDI KASUS DI KOTA KEBUMEN
}

\author{
Sigit Wibawanto \\ Program Studi Manajemen STIE Putra Bangsa-Kebumen \\ sigitpb3@gmail.com
}

\begin{abstract}
ABSTRAK
Tujuan penelitian ini adalah untuk mengetahui acara budaya dalam menghasilkan kunjungan destinasi di Kabupaten Kebumen. Metode yang digunakan dalam penelitian ini adalah pendekatan kualitatif untuk menganalisis daya tarik acara budaya pada kunjungan di acara tersebut. Acara budaya dibagi menjadi karnaval seni dan budaya. Responden/informan sebagai sumber informasi merupakan penyelenggara dan pengunjung pada acara budaya tersebut. Hasil dari penelitian ini menunjukkan bahwa acara budaya dilakukan untuk memperkenalkan budaya sebagai tujuan wisata yang menarik, dan melihat berbagai cara dan kegiatan kunjungan melalui pemenuhan kebutuhan segmen mereka. Hasilnya disajikan dan dapat berguna untuk mengembangkan kebijakan pariwisata yang ada di Kabupaten Kebumen, dengan strategi promosi yang terintegrasi sehingga tujuan kunjungan untuk tinggal lebih lama, bekerja, dan investasi dapat tercapai.
\end{abstract}

Kata kunci: acara budaya, kunjungan wisata, pendekatan kasus, tujuan Kebumen

\begin{abstract}
The purpose of this research is to find out cultural events in generating destination visits in Kebumen district. The method used in this study is a qualitative case approach to analyze the attractiveness of cultural events on visits at the event. Cultural events are divided into art and cultural carnivals. Informants as a source of information viewed from the organizers and visitors of cultural events. The research findings show that cultural events can be useful for introducing cultures as attractive tourist destinations, and viewing various ways and activities of visits through the fulfillment of their segment needs. The results are presented and can be useful for developing existing tourism policies in Kebumen district, with an integrated promotional strategy so that the purpose of the visit to stay longer, work, and investment can be achieved.
\end{abstract}

Keywords: cultural event, tourist visit, case approach, Kebumen destination 


\section{PENDAHULUAN}

Perkembangan industri wisata yang berkembang saat ini menunjukkan potensi yang meningkat untuk dikembangkan, seiring dengan kebutuhan untuk berwisata yang semakin meningkat. Perkembangan ini memunculkan kompetisi dalam pengelolaan untuk menarik para calon wisatawan yang berdampak pada aspek ekonomi suatu daerah dan masyarakat. Volume kunjungan yang tinggi tentunya akan membangkitkan potensi-potensi ekonomi yang bermunculan pada setiap daerah, yang tidak hanya sekedar di kelola oleh pemerintah, namun saat ini banyak tempat destinasi wisata, dimunculkan oleh pihak masyarakat maupun swasta. Begitu banyaknya pengelola tempat destinasi wisata, membuat para stakeholder yang berkaitan dengan pengelolaan wisata daerah perlu bersinergi untuk membangun kepercayaan calon wisatawan. Namun, bukan berarti sinergi tanpa persaingan, persaingan pengelolaan ini biasanya terjadi pada pengelolaan tempat-tempat destinasi wisata, dan dihadapkan pada meningkatnya persaingan antara satu sama lainnya. Kompetisi ini meliputi persaingan mendapatkan investasi luar, pengunjung, lokasi bisnis, serta keterlibatan dan keberpihakan masyarakat itu sendiri. Kompetisi merupakan usaha-usaha dari dua pihak/ lebih perusahaan yang masing-masing bergiat memperoleh pesanan dengan menawarkan harga/ syarat yang paling menguntungkan (Mudrajad K., 2005; 86).

Kompetisi dalam strategi pemasaran akan selalu bergerak dan mengikuti perubahan dan peradaban yang ada. Namun demikian tidak semua pergerakan kompetisi tidaklah bergerak dengan cepat. Pergerakan kompetisi yang lebih mobile adalah modal, orang dan perusahaan, menjadi tempat yang lebih menarik (Kotler et al. 1999). Pergerakan kompetisi yang melibatkan ketiganya juga terjadi pada pemasaran tempat, dan hal itu menjadi suatu dorongan untuk menjadi kajian ilmiah yang menjadi rangsangan untuk penelitian. Salah satu bagian dari pemasaran tempt yang membahas mengenai kunjungan wisatawan adalah pemasaran tujuan. Pemasaran ini bisa berjalan dengan baik jika pemangku kepentingan yang terlibat dalam pemasaran ini saling berintegrasi dan bekerja sama untuk membangun citra daerah sehingga pihak-pihak tersebut sama-sama memiliki kepedulian yang sama untuk membangun pemasaran tujuan. Diantara banyak upaya yang bisa dilakukan, salah satunya adalah dengan mengadakan berbagai acara yang menjadi sumber informasi dan daya tarik untuk pemasaran tujuan ini. Telah banyak literatur yang menyelidiki, membahas strategi pemasaran destinasi dan menyelidiki seberapa besar pengaruh acara-acara membentuk citra bagi negara maupun daerah yang menyelenggarakan mega-peristiwa. Alasannya adalah bahwa 
acara-acara tersebut akan membangun persepsi yang positif suatu daerah dan negara serta berdampak terhadap citra dan mendorong kunjungan serta investasi.

Pentingnya suatu acara besar bagi citra untuk membangun kesadaran maka dibutuhkan strategi yang lebih unik. Hal ini disebabkan suatu daerah ataupun negara sebagian besar juga melakukannya untuk mendorong kunjungan dan investasi. Sehingga agar daerah dan negara memiliki nilai lebih dibandingkan lainnya, perlu menciptakan posisi yang unik dan bernilai, dengan melibatkan sekumpulan aktivitas. Oleh karena itu, pemasaran destinasi harus memiliki keunggulan kompetitif yang dapat menarik kunjungan dan investasi melalui berbagai acara yang berbeda dan memiliki keunikan tersendiri dan terbuka bagi investor. Perbedaan yang menonjol yang bisa ditampilkan oleh suatu daerah atau negara diantaranya adalah acara-acara yang menjadi kebiasaan masyarakat setempat yang mampu terintegrasi dengan tempat-tempat yang mampu menarik kunjungan dan mendorong kunjungan untuk lama tinggal dan berinvestasi. Strategi yang mampu menarik kunjungan melalui acara akan sangat positif jika mampu mendorong terintegrasinya pemasaran tujuan lainnya pada suatu daeerah atau negara.

Pemasaran destinasi yang mampu terintegrasi dengan pemasaran destinasi lainnya akan mendorong pengunjung untuk lama tinggal dalam setiap kunjungannya dan pada akhirnya akan berdampak pada tumbuhnya investasi. Hal tersebut, mampu menjadi upaya yang lebih murah, efisien dan efektif untuk menarik pengunjung baru dan menahan serta melakukan kunjungan ulang bagi yang tertarik dengan acara tersebut. Hal tersebut seperti yang disampaikan Rosenberg et al. (1984) yang menyatakan bahwa lebih murah menahan pelanggan yang sudah ada daripada mendapatkan yang baru. Sehingga upaya itu menjadi sangat penting manakala penunjung mau mengulangi kunjungannya dan berpikir untuk lama tinggal dan mencari tujuan baru yang masih terlewat pada suatu daerah yang pernah dikunjunginya. Dengan demikian pemasaran ini sangat dekat dengan arah pemasaran hubungan dan pengelolaan hubungan dengan pelanggannya (Gummesson; 1999). Fokus penelitian kualitatif ini terletak pada pembahasan terbatas atau fokus untuk mengetahui kemampuan acara budaya dalam menghasilkan sebuah kunjungan, mencari tahu sesuatu yang terlewat dari suatu daerah yang pernah dikunjunginya dan mendorong untuk lebih lama tinggal pada daerah tersebut.

Acara budaya yang menjadi fokus dalam penelitian ini adalah adanya karnaval dan pentas seni budaya yang menjadi tugas dan tanggung jawab bagi para pemangku kepentingan baik pemerintah, masyarakat, maupun swasta yang berinvestasi pada daerah yang diteliti, yakni kabupaten Kebumen. Acara 
budaya yang dimaksud adalah dengan melihat bagian yang dijelaskan Ernst Cassirer (1990) yang membagi menjadi lima aspek budaya, yaitu dari sisi kehidupan spritual, bahasa dan kesustraan, kesenian, sejarah, dan ilmu pengetahuan. Tujuan penelitian ini adalah untuk mengetahui peran acara budaya dalam menghasilkan minat bagi wisatawan untuk berkunjung pada beberapa destinasi yang ditampilkan dalam acara budaya tersebut. Hasil dari penelitian ini diharapkan dapat menjadi masukan bagi pihak-pihak yang berkepentingan memandang pentingnya acara budaya yang bukan hanya menjadi kewajiban pemerintah daerah, namun peran masyarakat dan investor perlu terlibat dalam berbagai acara yang bisa menunjukkan daerah supaya dapat menghasilkan kunjungan baru, berulang dan mau berlama-lama tinggal pada daerah tersebut.

\section{Perspektif Teori}

Perspektif dalam penelitian ini merupakan cara pandang peneliti dalam memberikan kebebasan kepada responden untuk memberikan data atau informasi yang akan disajikan. Pendekatan kualitatif ini merupakan pendekatan penelitian yang datanya dalam bentuk narasi, cerita detail, ungkapan dan bahasa asli hasil konstruksi informan, tanpa evaluasi dan interpretasi yang diperoleh melalui wawancara mendalam dan observasi, bukan kuesioner. Tingkat kebebasan perspektif emik yang diberikan kepada responden atau informan sangat tinggi (Hamidi, 2010: 124-125). Paradigma merupakan perspektif riset yang digunakan peneliti untuk melihat realita (world views), mempelajari fenomena, cara-cara dalam penelitian dan caracara dalam menginterpretasikan temuan. Desain penelitian, menggambarkan pilihan suatu kepercayaan yang akan mendasari dan memberi pedoman seluruh proses penelitian (Guba, 1990). Paradigma menentukan masalah apa yang dituju dan tipe penjelasan apa yang dapat diterimanya (Kuhn, 1970).

Paradigma penelitian ini membahas pada aspek perilaku konsumen dan riset pemasaran mengenai perilaku dan keputusan berkunjung dari wisatawan yang beragam yang dihasilkan dari acara budaya yang diselenggarakan pemerintah daerah kabupaten Kebumen. Aktivitas kunjungan dapat menghasilkan keterkaitan manfaat diantaranya pengalaman pembelian dan perspektif yang dapat menyenangkan dirinya. Pencarian informasi, akan selalu dilakukan wisatawan melalui berbagai cara yang diarahkan dan mengeksplorasi perilaku untuk mencari pengalaman kunjungan yang dihasilkan dari acara budaya. Pencarian sejumlah informasi akan menjadikan dirinya memperoleh keuntungan dari perbandingan biaya dan manfaat untuk mengasumsikan sesuatu yang paling rasional, dari sudut pandangnya untuk melakukan kunjungan wisata. 


\section{TINJAUAN PUSTAKA}

\section{Pergeseran Place Marketing, Place Branding, dan Destination Marketing}

Pemasaran tempat merupakan sebuah fenomena dimana terdapat adanya keterlibatan diantara stakeholder, diantaranya adalah pemerintah daerah, pengusaha dan masyarakat. Keterlibatan ini dibahas dalam sebuah rencana dan kegiatan sebagai alat pemasaran untuk meningkatkan daya tarik tempat dalam kelompok sasaran yang berbeda. Kelompok sasaran sebagai segmen pemasaran tentunya pendekatannya akan berbeda dalam sebuah kepentingan pengunjung. Hal ini disebabkan karena setiap individu, kelompok, organisasi, utusan pemerintah mendapatkan informasi tempat yang dituju memiliki kebutuhan yang bervariasi. Sebagai contoh, bagi masyarakat individu kepentingan berkunjung bisa disebabkan karena kebutuhan pribadi untuk memenuhi hasrat pribadinya, baik aspek sosiologis, historis, gaya hidup, maupun psikologis. Masyarakat swasta/ perusahaan, maksud kunjungannya bisa disebabkan karena kontrak kerja, atau aktivitas bisnis yang mengharuskan maksud kunjungan tersebut harus dilakukan. Bagi masyarakat akademik/ peneliti maksud kunjungannya adalah tidak sekedar hanya untuk mengetahui fenomena saja, melainkan ingin melihat sebuah peradaban, strategi maupun upaya pengembangan obyek tujuan bisa menjadi sukses berdasarkan pikiranpikiran ilmiah. Sehingga dalam pemasaran tempat perlu dirancang dan dikembangkan strategi yang tepat dengan cara memenuhi kebutuhan setiap segmen sasarannya.

Rainisto (2003), menyampaikan bahwa keberhasilan pemasaran dapat berhasil jika masyarakat, perusahaan, merasakan kesenangan dan puas, serta harapannya bisa terpenuhi (Kotler et al. 1993). Oleh karena itu dalam pengembangan pemasaran tempat/ tujuan secara substansial perlu menyediakan suatu tempat yang ideal dan memenuhi kebutuhan segmennya. Pengembangan pemasaran tempat saat ini telah banyak mengalami perkembangan baik infrastruktur, manajemen, maupun promosi mengalami peningkatan. Bahkan saat ini banyak tempat yang menjadi obyek pemasaran ini kini dikembangkan mengarah pada penciptaan branding baik yang dikelola masyarakat wilayah/ lingkungan, perusahaan dengan investasinya, maupun pemerintah dalam menciptakan image daerah. Saat ini pembahasan tersebut, menjadi semakin menarik dalam pembahasan literatur pemasaran tempat yang berubah menjadi branding tempat (Karavatzis; 2005, Skinner; 2008).

Perbedaan diantara keduanya adalah, pemasaran tempat cenderung lebih konsen terhadap isu-isu masalah manajemen, sedangkan branding tempat 
cenderung lebih dikaitkan kepada tempat dalam upaya kegiatan promosi untuk penciptaan identitas yang berbeda pada benak berbagai kelompok sasaran. Oleh karena itu, pemasaran tempat selalu diarahkan pada target segmen yang berbeda, dan dalam penelitian ini hanya mempertimbangkan kepada segmen masyarakat individu wisatawan/ pengunjung terutama kunjungan yang disebabkan karena faktor acara budaya yang diselenggarakan oleh stakeholder acara budaya ini. Ada dua arah utama yang berbeda mengenai pembahasan mengenai pemasaran ini, yaitu: pertama, harus bisa membuktikan secara empiris mengenai target kelompok tertentu place marketing yang memiliki dampak kuat dan tergantung pada hasil (misalnya kepuasan tempat atau identitas tempat) dari satu untuk semua place branding. Kedua, kompleksitas fenomena yang beragam dari pemangku kepentingan place marketing, memberikan penawaran penelitian lebih lanjut tentang manajemen place marketing dalam kaitannya dengan menempatkan pemerintahan dan juga dalam membangun prosedur kebijakan bersama swasta, maupun masyarakat (Wibawanto, 2015).

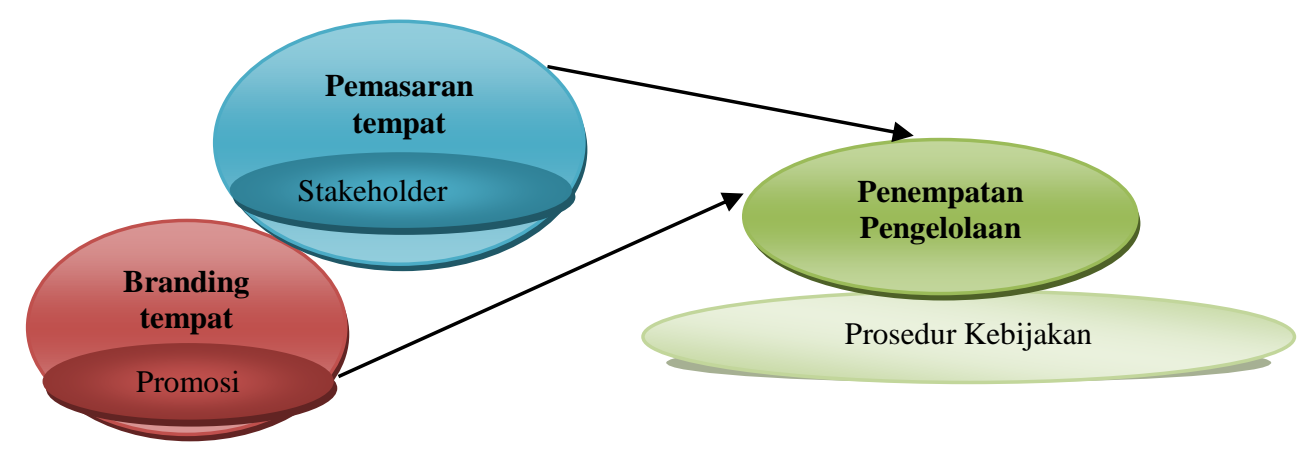

\section{Gambar 1. Deskripsi Pengelolaan Pemasaran Destinasi Baru Di Daerah}

Perlu diketahui bahwa segmen pengunjung mengenai pengaruh acara budaya terhadap pemasaran tempat pada saat itu, orientasinya kebanyakan bukan pada seberapa banyak dan lama kunjungan yang dilakukan oleh pengunjung. Namun hanya sekedar penampilan untuk pelestarian warisan budaya setempat dan memamerkan peradaban yang berkembang hingga acara tersebut dilakukan. Saat itu, pemasaran tempat belum menjadi pertimbangan para stakeholder, dan baru sekedar bagaimana memeriahkan suatu acara budaya tanpa melihat manfaat ekonomi yang bisa dihasilkannya. Padahal dalam pemasaran tempat, tujuannya bisa berkembang dan dapat membawa keberhasilan pada pemasaran destinasi yang menjadi alasan dilakukannya sebuah kunjungan. Era pada dua dekade terakhir, pembahasan mengenai pemasaran tempat telah menjadi sesuatu yang menarik. Dimana pada era 
tersebut, pembahasan diawali mengenai pengelolaan tempat menjadi sesuatu yang menarik dan mendorong kunjungan untuk wisata, investasi ataupun industri. Oleh karena itu, perkembangan mengenai kajian pemasaran tempat, masih menjadi sesuatu yang amat penting hingga saat ini. Begitu banyak tempat yang menawarkan peradaban suatu daaerah dengan melihat fakta-fakta sosiologis, historis dan teknologi, maka tingkat kompetisinya menjadi semakin bergairah. Hampir setiap tempat saat ini, telah banyak ditawarkan dan didorong promosinya untuk membangkitkan kesadaran terhadap suatu tempat untuk menarik lebih banyak kunjungan.

Pergeseran strategi, pada pemasaran tempat saat ini, pada akhirnya semakin kompetitif dan disadari tidak hanya menawarkan tempat, melainkan pada pemasaran yang menghasilkan kunjungan. Penawaran terhadap tempat dan pengelolaan kunjungan menyebabkan penggunaan istilah destination menjadi semakin populer, dan istilah place marketing mulai bergeser. Periode pergeseran penggunaan kata tersebut, saat ini terus terjadi, dan menggambarkan pemahaman mengenai tempat pariwisata. Istilah tempat didominasi pada artikel-artikel yang subjek pembahasannya pada jurnal bisnis dan branding. Skinner (2008) menyampaikan, mengenai pemasaran tujuan yang telah banyak memberikan kontribusi dalam memfasilitasi pencapaian kebijakan pariwisata, dan terkoordinasi dengan rencana strategis pembangunan daerah. Pemasaran tujuan juga memandu dan memberikan optimasi terhadap dampak pariwisata dan memaksimalkan manfaat bagi daerah. Buhalis (2000), Rainisto (2003), Skinner (2008) sama-sama menjelaskan bahwa bahwa literatur pemasaran tujuan saat ini juga bergeser pada aspek pengelolaan merek tempat. Literatur pemasaran tempat hanya menjelaskan bagaimana secara fisik geografis (alam atau sejarah) atau wilayah administratif (negara, kota, kabupaten, dll) saja (Rainisto 2003), sehingga definisi destinasi menjadi lebih kompleks. Buhalis (2000) juga menyatakan bahwa destinasi merupakan gabungan dari semua produk lokal yang ditawarkan, layanan, dan pengalaman. Lichrou, O'Malley dan Patterson (2008) menjelaskan mengenai destinasi yang tidak harus diperlakukan sebagai tempat statis dari aspek fisik saja. Destinasi merupakan fenomena dinamis, termasuk dalam aspek immaterial (mitos, budaya dll). Framke (2000) menyimpulkan bahwa destinasi merupakan tempat dengan identitas yang dihasilkan dari aktivitas, minat, infrastruktur dan daya tarik wisata. Destinasi tergantung pada tujuan pengunjung, Fennell (1996) mengungkapkan bahwa pengunjung dengan tujuan yang berbeda akan memiliki pola berperilaku yang berbeda pula. Misalnya beberapa pengunjung akan menghubungkan beberapa kegiatan acara budaya yang ada di suatu wilayah dengan beberapa tempat yang menyangkut beberapa acara yang dapat disaksikan oleh dirinya. 
Selanjutnya pengunjung akan mengunjungi beberapa tempat yang ada kaitannya dengan acara budaya yang dilakukan daerah dimana acara tersebut berlangsung. Oleh karena itu pemerintah daerah dapat memperlakukan sebagai acara budaya sebagai media promosi yang bisa diberikan kepada para pengunjung acara budaya tersebut. Melalui media tersebut, maka acara budaya menjadi salah satu upaya untuk membangun citra kota dan membangun kesadaran bagi pengunjung mengenai potensi wisata yang ada. Pentingnya acara budaya ini menjadi fokus dalam penulisan penelitian ini kaitannya dengan potensi kunjungan yang bisa dihasilkan.

Seperti diketahui bahwa, citra suatu daerah (kota/ kabupaten) akan mengacu pada bagaimana suatu daerah tersebut bisa mewakili secara nasional bahkan secara internasional, dan dapat memainkan peran penting dalam mempengaruhi persepsi dan pilihan berkunjung, tinggal, bahkan untuk melakukan bisnis di daerah tersebut (Morgan, Pritchard \& Piggott 2002). Oleh karena itu, daerah membutuhkan identitas dan karena itu sangatlah penting bahwa suatu destinasi perlu memiliki identitas yang unik (Lo, Mohamad, Songan dan Yeo, 2012). Sebagai contoh misalnya di negara Eropa dan Amerika; Paris, dipandang sebagai kota cinta, Oxford dipandang sebagai kota pendidikan, Liverpool dikaitkan dengan kota The Beatlest, Salzburg dengan musik khususnya Mozart. Di Indonesia juga dikenal kota-kota dengan predikat seperti itu, misalnya; Jogja sebagai kota pelajar, Bandung dikenal sebagai kota Paris van Java, Bali dengan pulau Dewata, dan lain-lain. Penciptaan itu tidaklah muncul dengan tiba-tiba, namun melalui perencanaan kota dengan identitas tersebut, akan membanggakan warga tentunya, dan akan meningkatkan keinginan memilih kota sebagai tempat hidup, bekerja, membuka toko, kunjungan, studi atau menemukan sesuatu yang lain dalam arti bisnis. Aplikasi yang efektif dan manajemen pemasaran destinasi dapat menyebabkan peningkatan aktivitas bisnis dan liburan dalam kota, pada gilirannya dapat menyebabkan pencapaian yang lebih tinggi dari pembangunan sosial dan ekonomi (Baker \& Cameron 2008). Menempatkan branding yang terkait dengan destinasi branding, lokasi branding dan pengembangan branding tempat, telah mendapatkan banyak perhatian. Meskipun tantangan yang ditimbulkannya dari produk tempatnya, teknik pemasarannya tumbuh dalam frekuensi yang meningkat dan dalam tingkat persaingan yang ketat. Oleh sebab itu, maka tempat harus secara efektif dikelola dan dikendalikan mereknya, termasuk kebutuhan yang menarik bisnis, pabrik, pengecer dan fasilitas rekreasi dan individu seperti warga, konsumen dan pengunjung (Kotler et al. 1993). Graham (2002) membuat perbedaan antara dua kota secara bersamaan, dimana yang pertama adalah kota eksternal, yang termotivasi dengan menciptakan identitas yang berbeda 
atau komoditas. Sedang yang kedua merupakan kota internal, kota pikiran yang fokus pada gaya hidup, keragaman dan pemangku kepentingan internal, diman persepsi kota tersebut didasarkan pada pengalaman individu dan kebutuhan.

Gambaran kota dengan merek yang unik, dapat berfungsi sebagai wahana bagi warga kota untuk mengidentifikasi merek kotanya. Selanjutnya dibawa ke permukaan, dibuat atau ditambahkan dengan melihat dua tujuan utamanya, yaitu menciptakan kesatuan citra dan menarik orang luar (turis, pengusaha, investor dll) dan memungkinkan proses terapi sosial, meningkatkan perkembangan moral dan spiritual dengan menciptakan rute psikososial di mana penduduk lokal menemukan diri mereka sendiri (Cozmiuc 2011). Dalam merancang strategi merek untuk sebuah kota, maka yang harus menjadi pertimbangan adalah pada saat menilai sumber dan aset kota yang dimiliki saat itu. Oleh karena itu, dalam melakukan strategi branding, kota/ daerah memanfaatkan aset nyata maupun yang tidak nyata melalui analisis situasi yang berupa tempat, orang, proses dan mitranya. Hal ini penting bagi pengembangan strategi branding kota yang dapat mengasumsikan identitas perkotaan, image perkotaan, reputasi dan nilai-nilai lokal yang dimiliki oleh kota tersebut (Cozmiuc 2011). Cozmiuc (2011) juga menyatakan bahwa ada empat sumber nilai tambah bagi kota, yaitu pengalaman orang di kota yang ditujunya, bagaimana orang-orang tersebut merasakan, keyakinan terhadap kota yang dituju, dan penampilan kota. Banyak kota melakukan strategi branding ini agar mampu mengingatkan para pengunjung bahwa ketika pengunjung menginginkan suatu kunjungan wisata maka pengunjung dapat mengingat dari acara-acara yang diselenggarakan oleh kota. Daerah biasanya menampilkan beberapa event yang terbuka untuk umum dan sifatnya gratis, sehingga seluruh warga dan pengunjung dapat menerima informasi dan menyampaikan ke banyak orang. Terlebih juga jika event di selenggarakan di daerah yang terdapat destinasi yang memungkinkan untuk dituju pengunjung.

\section{Promosi Sebagai Upaya Menghasilkan Minat Kunjungan}

Perilaku pengunjung biasanya dimulai dengan pencarian informasi, maksunya adalah, bahwa kunjungan dipengaruhi oleh faktor yang mempengaruhi pembelian produk wisata yaitu informasi mengenai produk dan jasa liburan. Wisatawan juga akan berbeda dalam cara mendapatkan informasi yang merupakan sumber yang digunakan sebelum membuat keputusan. Oleh karena itu, banyak lembaga pemerintah, agen perjalanan, dan bisnis wisata berupaya membuat informasi untuk mengedarkan kepada pengunjung. Investasi tinggi dikeluarkan untuk melakukan upaya komunikasi dan promosi, hal ini karena masih banyaknya pengunjung yang masih kurang terhadap 
pengetahuan yang bisa dijadikan sumber informasi yang dapat digunakan untuk membuat pilihan kunjungan. Melalui informasi mengenai tujuan yang konkret sering diminta wisatawan dan menjadi sarana penting dalam kegiatan promosi yang penting bagi industri pariwisata. Sumber informasi destinasi memiliki pengaruh besar bagi proses pengambilan keputusan dan perilaku wisatawan, dimana akan menentukan bagaimana cara mencari informasi dan bagaimana cara informasi akan digunakan (Andereck dan Caldwell, 1993). Sumber informasi kunjungan terdiri dari sumber formal dan sumber informal. Sumber informasi dari informal, diantaranya brosur (promosi) dan sumber informal, misalnya kerabat dan teman-teman, juga memiliki pengaruh pada pembentukan citra tujuan turis (Beerli dan Martin, 2004). Promosi akan memberikan banyak fungsi dalam tingkatan yang berbeda sebagai cara yang praktis untuk menyampaikan ide dan pesan. Melalui promosi ini, citra dan representasi pariwisata dapat memainkan peran penting dalam menentukan perilaku pembelian wisata. Woodside dan Lysonski (1990) menunjukkan adanya hubungan nyata antara persepsi tujuan dan keputusan pembelian yang positif. Demikian pula, dengan citra yang negatif, meskipun benar, akan menentukan calon wisatawan dan hasilnya akan memutuskan untuk tidak membeli (Morgan dan Pritchard, 1998).

Pembentukan citra merupakan upaya pengembangan dari gagasan mental berdasarkan tayangan terbatas yang berasal dari sumber informasi tunggal. Pada image destinasi wisata, informasi ini berasal dari banyak dan beragamnya sumber (Gartner, 1994). Pertama, informasi diinduksi termasuk dari materi promosi (brosur, poster), serta operator tur dan pendapat agen wisata. Kedua, self-informasi yang memainkan peran dan diperoleh melalui media massa dan budaya yang populer. Terakhir, informasi yang berasal dari teman dan kerabat, serta pengalaman pribadinya. Banyak orang akan menjadikan citra destinasi yang didapat dari berbagai sumber informasi, dipilih informasinya dari yang paling akurat, komprehensif, dan dari pribadi yang terbentuk saat destinasi benar-benar dikunjunginya. Penulis dalam pembahasan ini hanya menyajikan pada konteks promosi melalui agenda acara budaya yang diselenggaarakan oleh pemerintah daerah, masyarakat, maupun organisasi. Hal ini dibatasi pada aspek tersebut karena metode promosi tersebut menurut persepsi sementara penulis memiliki kemampuan menghasilkan minat kunjungan wisatawan. Disamping itu, menurut pemahaman penulis wisatawan sering kali tidak dapat mengevaluasi mengenai nilai komoditi untuk produk-produk wisatanya. 

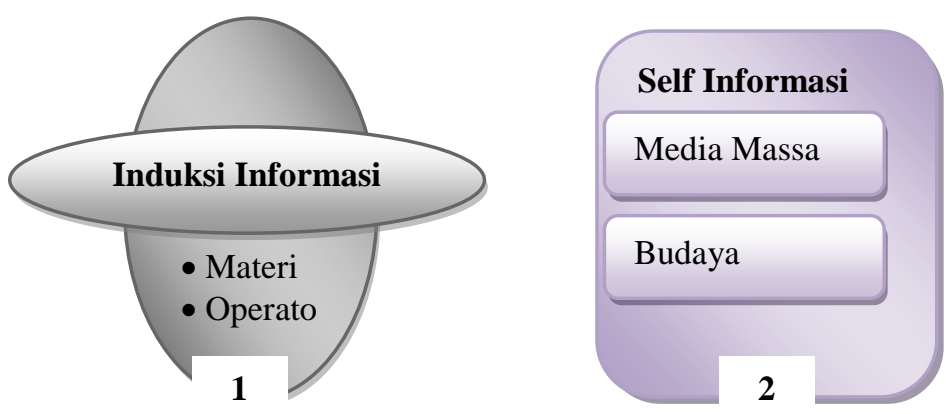

- Teman dan Kerabat

- Pengalaman

\section{Gambar 2. Pembentukan Image Destinasi Wisata}

\section{Acara Budaya Sebagai Bagian Dari Pemasaran Destinasi}

Destinasi wisata dalam suatu pemasaran biasanya identik dengan diselenggarakan berbagai acara. Ada beberapa cara untuk mengkategorikan peristiwa menjadi suatu acara yang dapat menarik suatu kunjungan. Berdasarkan temanya acara, bisa dibedakan menjadi tiga jenis acara, yaitu acara bisnis, permainan olah raga, dan perayaan budaya. Kategorinya pun berdasarkan pada ukuran peristiwanya acara (tingkat lokal, regional, ciri, dan peristiwa besar) dan juga didasarkan pada periodisasi acara (acara insidenta dan berkala). Acara dapat memainkan peran penting dalam pembangunan masyarakat, pembaharuan perkotaan, pengembangan budaya dan dalam membina identitas nasional (Getz 2008). Getz (2008), Todds dan Joppe (2001), menunjukkan bahwa mega acara dari budaya, olahraga, dan festival dapat sebagai strategi pengembangan kota melalui pembangunan infrastruktur dan penciptaan image antara ketiga kegiatan strategis tersebut. Wood (2005) menyatakan bahwa jika pemerintah daerah merencanakan peristiwa yang strategis, maka sangat penting secara sistematis dikumpulkan data secara obyektif setelah peristiwa dari pelaksanaan acara. Pada aspek ini penulis membatasi pada karakteristik acara, yaitu acara budaya. Acara ini merupakan salah satu dukungan yang paling penting dari bisnis pariwisata, dan seringkali dalam acara tersebut, ditonjolkan seorang tokoh bersejarah, tempat wisata, infrastruktur, seni dan kerajinan yang menonjol dalam pengembangan dan rencana pemasaran destinasi. Melalu acara budaya diharapkan diperoleh manfaat dari suatu tujuan pemasaran melalui model ini, diantaranya menghasilkan langsung arus kas belanja turis (Wood, 2005; Breen et al, 2001), membawa wisatawan ke daerah selama acara (Getz 2008; McCartney 2005), membuat image positif dan perbedaan destinasi (Hede 2005; Richards et al 2004.; Kaplanidou et al. 2007), menciptakan kesadaran melalui media massa (Green 2003), serta memenuhi tujuan pemasaran destinasi untuk 
menjadi tempat terbaik untuk hidup, bekerja, dan investasi. (Getz 2008; Wood 2005). Tulisan ini fokus pada membawa wisatawan pada beberapa daerah yang diminati wisatawan untuk dikunjungi.

\section{METODE PENELITIAN}

Setiap penelitian selalu akan disesuaikan dengan metodologi penelitiannya. Melihat dari jenis datanya, dalam penelitian ini, penulis menggunakan pendekatan kualitatif. Kirk dan Miller (dalam Moleong, 2010: 4), mendefinisikan penelitian kualitatif sebagai tradisi dalam ilmu pengetahuan sosial yang secara fundamental bergantung pada pengamatan manusia dalam kawasannya sendiri dan berhubungan dengan orang-orang tersebut dalam bahasannya dan peristilahannya. Pendekatan kualitatif dimaksudkan untuk memahami apa yang dialami subjek penelitian secara holistik, dan dengan cara deskripsi dalam bentuk kata-kata dan bahasa, pada suatu konteks khusus yang alamiah dan dengan memanfaatkan berbagai metode ilmiah (Moleong, 2007:6). Penelitian kualitatif ini menggunakan pendekatan studi kasus untuk menelaah sebuah/ beberapa kasus dari konteks nyata yang fokus pada beberapa peristiwa, dan didasarkan pada tujuan untuk mengilustrasikan peran acara budaya yang memiliki peran unik dalam mempengaruhi dan menghasilkan kunjungan pada suatu destinasi wisata budaya.

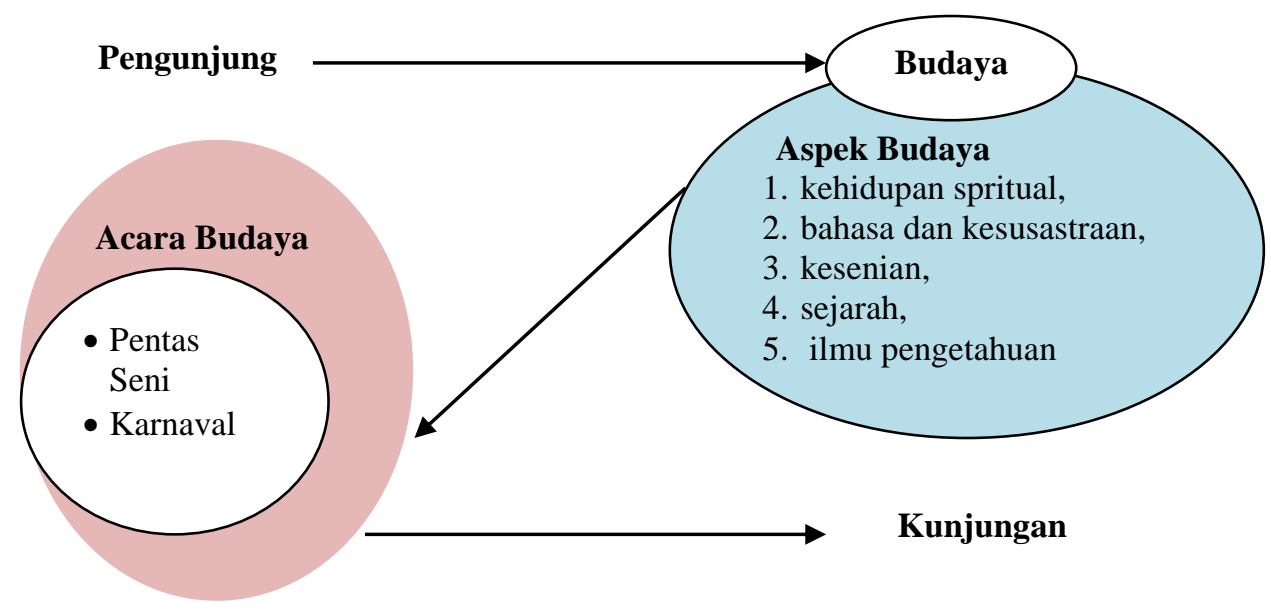

\section{Gambar 3. Budaya yang mungkin dapat mempengaruhi kunjungan}

Batasan ilmiah dalam penelitian ini menggunakan acuan yang dijadikan pedoman dalam penelitian, yaitu acara budaya yang bermanfaat untuk memperkenalkan budaya dan tempat tujuan wisata yang berguna untuk menarik, dan menghasilkan berbagai cara dan aktivitas kunjungan wisata. Unit analisis dalam penelitian ini adalah satuan yang diteliti yaitu individu, 
kelompok, benda atau suatu latar peristiwa budaya sebagai subjek penelitian. Hal ini untuk mengungkap data dengan menetapkan kriteria responden yang menjadi subjek penelitiannya dengan teknik purposive sampling. Peneliti melakukan hal pertama dengan menemukan informan dan partisipan pertama yang dapat memberi informasi yang memadai saat peneliti mengawali aktivitas pengumpulan data. Setting penelitian dilakukan dengan mewawancarai informan saat melihat penyelenggaraan acara budaya dan menunjukkan respon saat ditanya mengenai destinasi yang menarik untuk dikunjunginya suatu saat nanti di kabupaten Kebumen dengan membagi persebaran wilayah barat dan timur sungai Luk Ulo. Pembagian ini tidak bermaksud untuk membedakan wilayah barat dan timur sungai Luk Ulo, hanya dimaksudkan untuk memudahkan dalam pemetaan, dan strategi untuk penelitian selanjutnya. Acara budaya ini, dibagi menjadi lima aspek budaya, yaitu dari sisi kehidupan spritual, bahasa dan kesusastraan, kesenian, sejarah, dan ilmu pengetahuan (Ernst Cassirer, 1990). Waktu penelitiannya adalah insidental pada saat acara budaya diselenggarakan, serta menekankan wawancara pada motivasi penyelenggara dan perilaku wisatawan saat mengunjungi acara tersebut. Budaya yang diamati pada proses penelitian ini berupa pentas seni budaya dan karnaval budaya. Pentas seni budaya yang diamati dalam penelitian ini, diantaranya: jamjaneng, wayang kulit, kuda lumping, tari dansak, ebeg, cepetan, dan karawitan. Sedang pada karnaval budaya, diantaranya: arak-arakan sedekah bumi dan laut, merdi desa, grebegan bulan suran (larungan di pesisir pantai selatan), dan peringatan khaul tokoh ulama setempat. Strategi penelitian ini menggunakan strategi dengan beberapa tahapan yaitu tahap perencanaan, tahap pelaksanaan, observasi, dan tahap refleksi peneliti. Pengumpulan data dalam penelitian ini melalui observasi, wawancara, catatan lapangan, dan dokumentasi.

Keabsahan data merupakan keakuratan antara data yang terjadi pada obyek penelitian dengan data yang dilaporkan peneliti. Data yang valid adalah data yang tidak berbeda antar data yang dilaporkan oleh peneliti dengan data yang sesungguhnya terjadi pada obyek penelitian (Sugiyono, 2005, p. 117). Penelitian ini menggunakan uji keabsahan data uji kredibilitas triangulasi, transferabilitas, dan dependabilitas. Analisis data kualitatif pada penelitian ini diperoleh dari data kualitatif yang wujudnya adalah kumpulan kata-kata dan tidak dapat disusun dalam kategori-kategori/ struktur klasifikasi. Kegiatan analisis terdiri dari empat alur/ siklus kegiatan, yaitu pengumpulan data, reduksi data, penyajian data, dan penarikan kesimpulan/ verifikasi yang dilakukan secara bersamaan. 


\section{HASIL DAN PEMBAHASAN}

\section{Gambaran Lokus Penelitian}

Budaya pada lokus penelitian ini melihat dari sejarah kabupaten Kebumen yang menarik untuk diselidiki, mengingat masih sangat sedikit penulis yang menyajikan kajian ilmiah terhadap hal ini. Secara geografis kabupaten ini memiliki letak sebagai daerah yang memiliki dataran rendah dan perbukitan yang merupakan rangkaian perbukitan serayu selatan. Sebagian besar masyarakat di wilayah ini secara ekonomi merupakan petani dan menurut sejarahnya pernah menjadi kawasan lumbung padi yang menjadi pemasok logistik pada masa kerajaan mataram dibawah kepemimpinan Sultan Agung. Sehingga tidak aneh bahwa kabupaten Kebumen secara historis memiliki kedekatan emosional dengan Mataram yang pada akhirnya mempengaruhi segala aspek kehidupan masyarakat Kebumen pada saat itu. Disamping itu, peradaban yang mulai berkembang pada pemerintahan pada saat itu, pengaruh peradaban Surakarta juga masuk ke Kebumen pada era Pakubuwono I yang mengirimkan Tumenggung Arungbinang I untuk mengatasi pemberontakan di Banyumas. Sehingga pengaruh era peradaban Surakarta juga ikut masuk ke wilayah Kebumen, bahkan sampai pada wilayah Banyumas. Melihat sejarah yang begitu panjang dan mempengaruhi segala aspek kehidupan masyarakat Kebumen saat itu, maka masyarakat wilayah ini dari segala kehidupannya terbawa pada akulturasi budayanya dalam aktivitasnya.

Akulturasi kehidupan sehari-hari yang ada di kabupaten ini pada akhirnya menyebabkan adanya perbedaan dalam setiap kehidupan sosialnya, diantaranya adalah masalah bahasa yang memiliki keunikan, terutama lafadznya. Keanekaaragaman tersebut sebagai identitas sosial yang membangun solidaritas dan kekuatan masyarakat Kebumen, yang berasal dari dua kutub kebudayaan Bagelen dan Banyumas. Melihat begitu uniknya budaya wilayah kabupaten ini, maka penulis akan membahas dari aspek kebudayaan yang dimunculkan dari aspek pengaruh budaya dari dua kutub yang berbeda dari tanah jawa yang dibatasi fokus acara budaya yang diselenggarkan hingga saat ini sesuai dengan peradabannya ini. Acara budaya yang menjadi kajian penelitian ini adalah jangkauan kebudayaan yang mengacu pada pembahasan dari Ernst Cassirer (1990) yang membaginya menjadi lima aspek acara budaya kehidupan spritual, bahasa dan kesustraan, kesenian, sejarah, dan ilmu pengetahuan.

Aspek acara budaya dari sisi kehidupan spritual akan dilihat mencakup kebudayaan fisiknya, seperti sarana (candi, patung nenek moyang, 
arsitektur), peralatan (pakaian, makanan, alat-alat upacara). Sistem sosial, seperti upacara-upacara (kelahiran, pernikahan, kematian). Adapun aspek bahasa dan kesusteraan mencakup bahasa daerah, pantun, syair, novel-novel. Aspek seni dapat dibagi menjadi dua bagian besar, yaitu: visual arts dan performing arts, yang mencakup: seni rupa (melukis), seni pertunjukan (tari, musik), seni teater (wayang), seni arsitektur (rumah, bangunan, perahu); aspek ilmu pengetahuan meliputi science (ilmu-ilmu eksakta) dan humanities (sastra, filsafat, kebudayaan, sejarah, dsb.).

\section{Temuan Penelitian}

Berdasarkan observasi yang dilakukan, penelitian menemukan bahwa acara budaya yang terdapat di kabupaten Kebumen, belum ada yang terintegrasi secara baik dengan aspek ekonomi. Berdasarkan apa yang disampaikan beberapa informan yang ditemukan di lapangan yakni 12 penyelenggara acara budaya dan 12 pengunjung, berdasarkan permasalahan penelitian, ternyata belum memberikan dampak pada aspek kunjungan wisatawan. Estimasi yang diberikan informan membuktikan bahwa acara budaya tersebut belum diintegrasikan dengan upaya promosi untuk membangun potensi wisata tersebut bagi wilayahnya, dan sebagian besar informan menyampaikan hanya sebagai upaya bakti terhadap nenek moyang dan kebiasaan dari masyarakat sebelumnya. Berikut hasil estimasi yang disampaikan penyelenggara berdasarkan pengunjung yang hadir pada saat pentas seni budaya dilaksanakan.

\section{Gambar 4. Estimasi Persebaran Kunjungan Pada Acara Pentas Budaya}

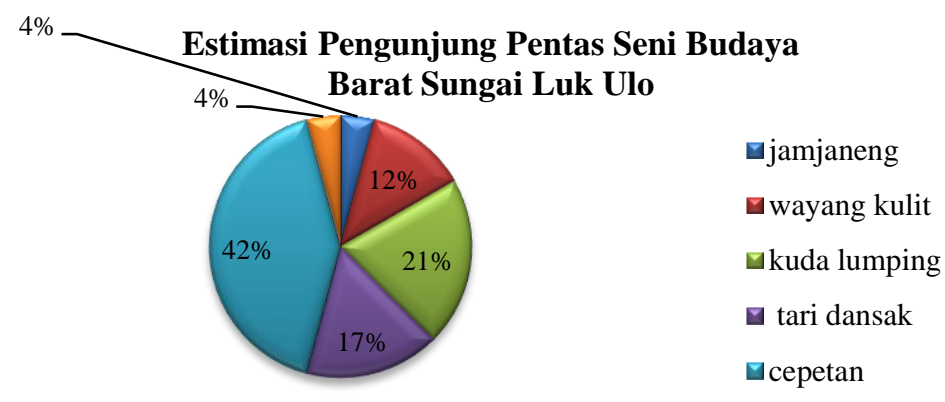




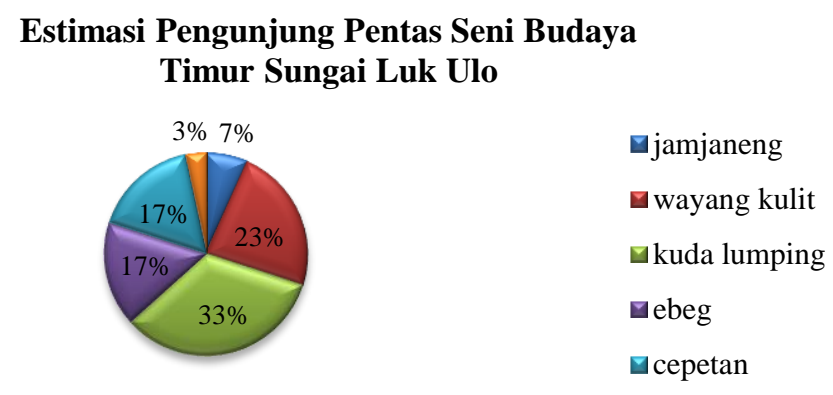

Dari gambar diatas terlihat bahwa untuk masing-masing lokasi persebarannya, menunjukkan bahwa masyarakat untuk pentas budaya barat sungai Luk Ulo, cenderung lebih banyak mengunjungi pada pentas yang menunjukkan pada nuansa tarian (cepetan) yang dapat membangkitkan kunjungan. Sedangkan timur sungai Luk Ulo nuansa tarian (kuda lumpimg), juga dapat membangkitkan kunjungan meskipun berbeda istilah dan penokohannya.

Acara karnaval budaya yang diamati peneliti berdasaran informan penelitian (penyelenggara) menunjukkan persebaran estimasi pengunjung sebagai berikut:

\section{Gambar 5. Estimasi Persebaran Kunjungan Pada Karnaval Budaya}

Estimasi Pengunjung Karnaval Budaya

Barat Sungai Luk Ulo

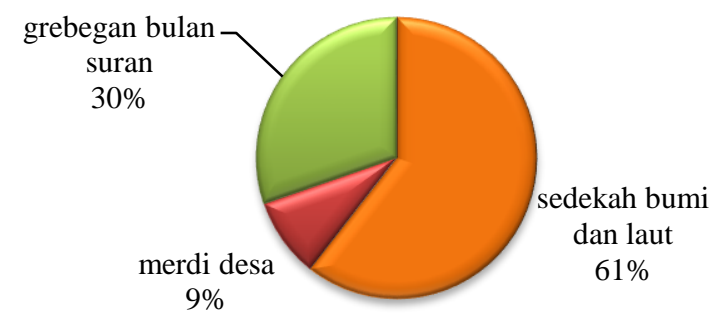

Estimasi Pengunjung Karnaval Budaya Timur Sungai Luk Ulo

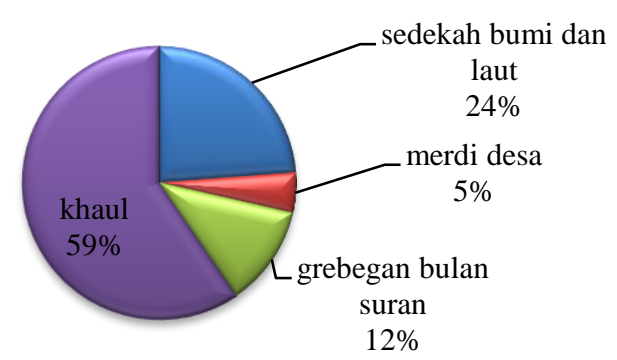


Karnaval budaya yang menunjukkan adanya perbedaan dalam maksud dan kunjungan menghadirinya. Secara kebetulan berdasarakan informasi informan, diperoleh bahwa karnaval yang berupa arak-arakan budaya pada masyarakat barat sungai Luk Ulo menunjukkan dampak luar biasa pada aspek kunjungan, meskipun tidak lain dengan timur sungai Luk Ulo. Namun acara-acara karnaval budaya pada timur sungai ramai pada acara-acara yang berupa peringatan penokohan ulama-ulama yang sebelumnya memiliki kelompok pesantren yang dibangun pada masa itu.

Wilayah persebaran pengunjung berdasarkan informasi yang ditemukan di lapangan, untuk penyelenggaraan acara budaya rata-rata terbagi dalam radius jarak tempuh pengunjung. Hal ini dapat digambarkan sebagai berikut:

\section{Gambar 6. Persebaran Pengunjung Acara Budaya}
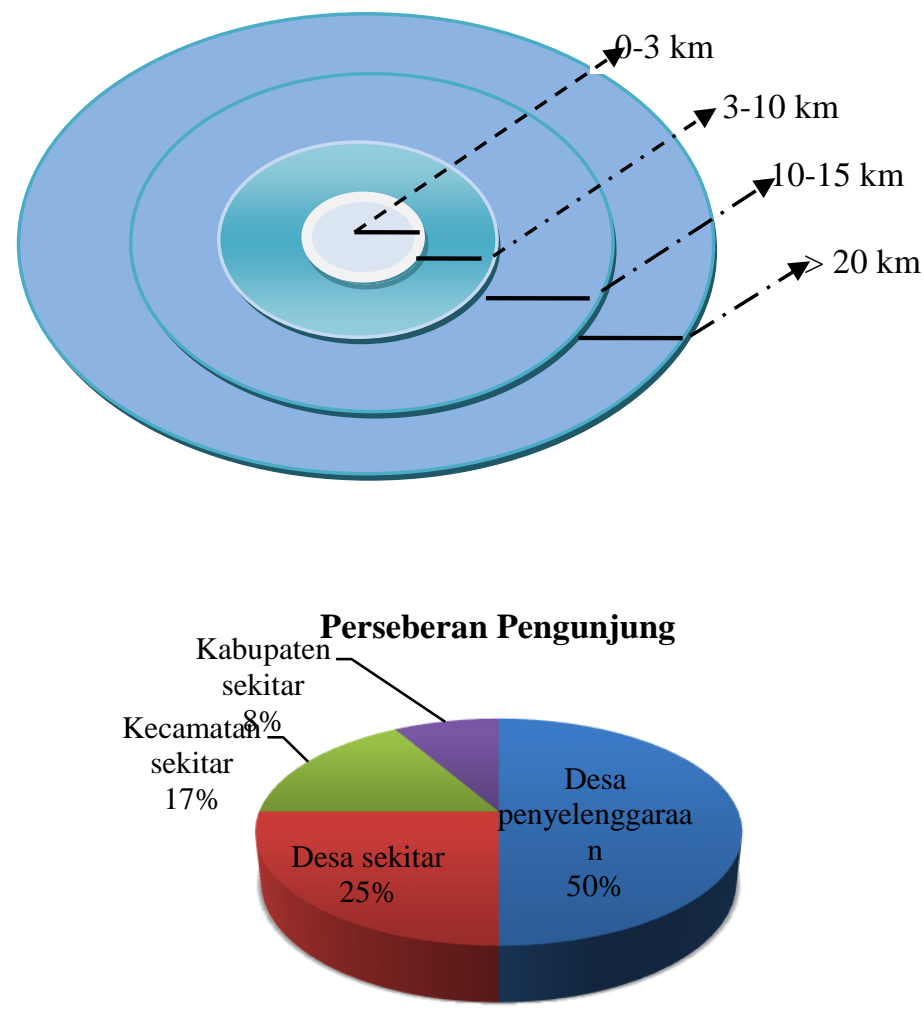

Persebaran pengunjung menunjukkan bahwa penyelenggaraan acara-acara budaya di kabupaten Kebumen masih menunjukkan bahwa, pengunjung sebagian besar masih didominasi oleh warga disekitar penyelenggaraan dan desa sekitarnya. Hal ini menunjukkan bahwa potensi kunjungan bagi 
masyarakat yang lebih luas belum tercapai atau belum ada upaya untuk menunjukkan kepada masyarakat luas. Sebagian besar pengunjung juga hanya mengakses kunjungannya dengan jalan kaki, sepeda/ sepeda motor, dan sebagian kecil mobil. Selain itu dari beberapa pengunjung yang menjadi informan penelitian juga menyampaikan bahwa kunjungan terhadap acaraacara tersebut disebabkan karena faktor-faktor sebagai berikut:

\section{Gambar 6. Alasan Kunjungan}

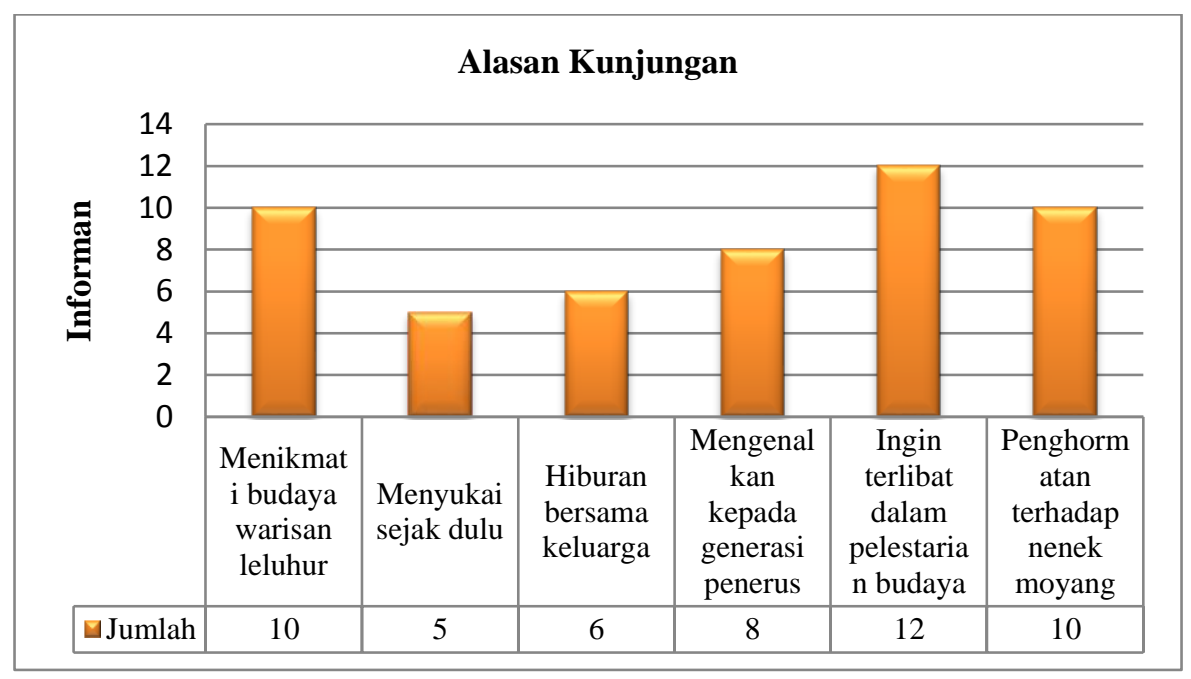

Aspek acara budaya yang dibahas dalam acara budaya, dengan wawancara informan baik penyelenggara maupun pengunjung yang menghadiri acara tersebut, ditemukan bahwa:

a. Sub fokus pada sisi kehidupan spiritual

Kehidupan masyarakat Kebumen begitu religius, dimana ketaatan terhadap keyakinan spiritual memungkinkan masyarakat di wilayah ini menjadi sangat patuh dan mengikuti warisan ritual dari generasi sebelumnya. Sebagian besar budaya di wilayah ini diidentikkan dengan ritual agama, dan menjadi sesuatu yang tidak mudah dipisahkan. Kepercayaan bahwa spiritual dalam setiap aktivitas kehidupannya melibatkan berbagai pandangan mengenai hubungan dengan pencipta-Nya dan sesama manusia. Pada wilayah Kebumen ini budaya yang dilihat dari sisi kehidupan spiritual diantaranya Khaul Syech Ibrahim Asmorokondi di Panjer Kebumen, Baritan (sekedah laut) di kecamatan Mirit, shalawat Jamjaneng, ritual panen sarang burung Walet di Karangbolong, ritual cah angon urut sewu di Ambal, kirab pusaka di Karanganyar, dan masih banyak lainnya, di luar jangkauan peneliti. Temuan peneliti menunjukkan bahwa ketika acara ini dilaksanakan menurut informan dipercaya sebagai; 
ungkapan syukur, menghindari sesuatu hal yang tidak diinginkan (panen kurang, wabah dan marabahaya, membuang sifat buruk), dukungan terhadap penyebaran agama (Islam), ungkapan persaudaraan dan kemakmuran.

b. Sub fokus pada sisi bahasa dan kesusastraan

Pergaulan sosial masyarakat kabupaten Kebumen dihubungkan dengan menggunakan tutur bahasa jawa dalam kesehariannya. Berdasarkan informasi dari informan, diketahui bahwa Kebumen sebagian besar acara dan pentas budayanya menggunakan bahasa dan kesusastraan jawa. Akan tetapi jika mendengar logat bahasanya, masyarakat kabupaten ini terbagi dalam beberapa logat/ dialek. Bagian timur dari aliran Sungai Kedungbener yang melintasi kabupaten ini sebagian wilayahnya berbahasa dengan logat Bagelen dan Kedu. Sementara itu pada bagian barat dari aliran sungai Luk Ulo dialek yang dituturkan didominasi logat Banyumasan. Sedangkan jika diperhatikan masyarakat di wilayah bagian utara kecenderungannya lebih fasih berbicara dengan logat Wonosoboan. Temuan peneliti bahwa dalam acara budaya maupun pentas seni budaya bahasa ini juga dapat menjadi daya tarik sendiri bagi pengunjung untuk mempelajari bahasa jawa krama inggil yang sudah mulai luntur dalam kehidupan keseharian masyarakat setempat.

c. Sub fokus pada sisi kesenian

Salah satu unsur budaya universal yang menjadi cerminan peradaban manusia adalah kesenian. Seni cenderung dipandang sebagai ekspresi dan produk budaya yang berkaitan dengan sistem sosial masyarakat (Macaryus, 2008:105-106). Pendapat ini terkait dengan seni yang mengandung nilai-nilai dan pengalaman estetika dalam perilaku atau aktivitas berkesenian yang dikembangkan masyarakat, baik berupa bentuk atau produk seni yang dapat dinikmati secara kasat mata. Temuan penelitian kali ini berdasarkan informan, kesenian tradisional sebagai warisan budaya saat ini di kabupaten Kebumen mengalami penurunan terhadap nilai-nilai masyarakatnya. Nilai tersebut, diantaranya pendidikan, religius, sosial, hiburan, moral, etika, dan estetika. Hal ini dibuktikan dengan karya seni tersebut sudah mengalami penurunan terhadap fungsifungsi yang ada di masyarakat, yaitu rasa keindahan sebagai masyarakat jawa yang mengedepan sopan santun, sosial dan keramahtamahan, norma dalam sistem patrialisme telah banyak diabaikan dan berubah ke arah modernitas. Sisi lain dari penurunan nilai dari sebab terbatasnya kesenian tradional tersebut, masih banyak yang merindukan dan menginginkan budaya tersebut muncul kembali. Berbagai pandangan terhadap keinginan munculnya dan bertahannya budaya tradisional justru ada pada generasi $\mathrm{X}$, 
yang menginginkan generasi penerusnya mengaplikasikan nilai-nilai yang ada pada kesenian tersebut.

d. Sub fokus pada sisi sejarah

Sejarah budaya yang membentuk masyarakat kabupaten Kebumen dari hasil akulturasi, menyebabkan pandangan mengenai sejarah terbentuknya budaya menjadi bervariatif. Akulturasi yang memakai budaya luar sebelumnya, kebanyakan dianut masyarakat kebumen bagian barat sungai Luk Ulo, yang lebih banyak menggunakan adat istiadat Banyumasan, padahal sebenarnya pada era tersebut Kebumen di bawah pengaruh pemerintah keraton Mataram. Sedang asimilasi, terjadi pada bagian masyarakat Kebumen bagian utara, yang tampak bahwa budaya masyarakatnya menggunakan budaya pemerintahan keraton Mataram, namun dalam struktur bahasa masih menggunakan bahasa Wonosoboan. Temuan peneliti ini berdasarkan informan yang ditemui menunjukkan bahwa Kebumen, memiliki keunikan yang dikenal oleh masyarakat di luar kabupaten Kebumen cenderung lebih condong ke budaya Banyumasan, namun fakta di dalamnya terdapat budaya lain (Bagelen dan Wonosobo). Berdasarkan informasi diperoleh bahwa sebagian besar aktivitas kunjungan yang dilihat dari sisi sejarah adalah melihat bagaimana pelaksana kegiatan menggambarkan dan menceritakan munculnya budaya setempat mengingatkan pada generasi setempat, berupa nilai, moral, etika yang dianut generasi nenek moyangnya.

e. Sub fokus pada sisi ilmu pengetahuan

Perkembangan budaya identik dengan peradaban yang selanjutnya mempengaruhi ilmu pengetahuan. Peradaban saat ini, merupakan adanya proses akulturasi dan asimilasi yang menyebabkan budaya berkembang ke arah yang lebih modern, termasuk pada masyarakat kabupaten Kebumen. Akibatnya budaya yang berkembang pada zaman dahulu mulai pudar, bahkan akan punah. Berdasarkan informan, kegiatan rata-rata dimaksudkan untuk menyampaikan bahwa kegiatan pentas seni dan karnaval yang dilakukan, adalah untuk menunjukkan ke masyarakat Kebumen dan sekitarnya, bahwa pada saat itu Kebumen memiliki peradaban yang luar biasa dari sisi pengetahuan. Keberhasilan nenek moyang ditampilkan dalam setiap acara tersebut, yang dimunculkan melalui simbol-simbol, ataupun atribut-atribut, ataupun pagelaran. Hal ini dimaksudkan bahwa peradaban ini bisa membawa semangat bagi masyarakat Kebumen, melalui pesan moral dan nilai yang dibawa dalam kegiatan tersebut.

\section{Pembahasan Temuan Penelitian}


Berdasarkan hasil temuan menunjukkan bahwa dalam aktivitas budaya ternyata menyimpan banyak potensi kunjungan dari masyarakat yang perlu dilakukan upaya perbaikan untuk dikembangkan. Pembahasan ini dilakukan dengan melihat temuan pada sub fokus penelitian.

a. Sub fokus pada sisi kehidupan spiritual

Religiusitas yang dimiliki masyarakat kabupaten Kebumen telah ditunjukkan dengan ketaatan keyakinan spiritual yang memungkinkan masyarakat masih patuh dan mengikuti warisan ritual yang dilakukan secara temurun. Kepercayaan kepada sang pencipta memungkinkan digali bentuk-bentuk peninggalan yang perlu dilestarikan sebagai upaya menunjukkan peradaban spiritual. Penokohan nenek moyang dan agama menjadi acuan dalam berbagai kegiatan sebagai penyeimbang untuk mengikuti peradaban saat ini. Hal ini memungkinkan bahwa budaya dalam kehidupan spiritual sangat memungkinkan untuk diberdayakan sebagai potensi ekonomi untuk berkunjung, menetap, dan bekerja dengan suasana yang religius.

b. Sub fokus pada sisi bahasa dan kesusastraan

Sosial masyarakat kabupaten Kebumen yang terbentuk melalui akulturasi dan asimilasi budaya memungkin peradaban ini dibangun dengan berbagai budaya yang memungkinkan masyarakat Kebumen bisa menerima perbedaan. Peleburan ini menjadi kekayaan tersendiri dengan menambah kekayaan budaya yang dimiliki, namun demikian kelemahannya adalah menyebabkan budaya asli setempat. Sehingga upaya mengidentifikasi berdasarkan budaya perlu dipertahankan tanpa menghilangkan sistem sosial budaya Kebumen, yang dapat meningkatkan nilai-nilai budaya sebagai aspek ekonomi yang perlu digali.

c. Sub fokus pada sisi kesenian

Kesenian yang ada di kabupaten Kebumen, menunjukkan bahwa semua budaya yang masih terjaga saat ini adalah nilai yang diharapkan akan selalu terjaga di masyarakat. Nilai-nilai seni yang terkandung dalam budaya akan tidak pernah lepas dari sisi pendidikan, religius, sosial, hiburan, moral, etika, dan estetika. Kehidupan ke arah modernitas yang tidak lepas dengan peradaban saat ini bisa menjadi penghambat seni mulai terpinggirkan, namun jika upaya ini dimulai sejak dini, dan diberikan kepada dunia pendidikan tentunya akan dapat membawa keberlanjutan pada aspek nilai budaya tersebut.

d. Sub fokus pada sisi sejarah

Keunikan masyarakat kabupaten Kebumen adalah masyarakat yang merupakan peralihan dari dari dua kebudayaan yang berbeda dan akhirnya melahirkan akulturasi dan asimilasi yang menarik. Gambaran dan 
cerita munculnya daerah ini tentunya akan berakibat pada sejarah pendiriannya. Hal ini terbukti bahwa terbentuknya kabupaten Kebumen masih menjadi perdebatan para pemerhati dan ahli sejarah budaya yang meneliti terbentuknya pemerintahan dilihat dari sejarah budaya yang ada dan birokrasi pada saat itu. Perdebatan ini tentunya akan berpengaruh terhadap informasi bagi generasi selanjutnya. Budaya sebagai salah satu terbentuknya sejarah pemerintahan ini tentunya tidak boleh hilanga agar nilai, moral, etika yang dianut generasi pada saat ini tidak luntur dan mampu menyesuaikan peradaban saat ini. Oleh karena itu ini akan menjadi peristiwa yang menarik yang tentunya bisa membawa bagi pengunjung yang ingin mengetahui peradaban saat itu.

e. Sub fokus pada sisi ilmu pengetahuan

Kegiatan pentas seni dan karnaval merupakan suatu alat untuk menunjukkan ke bukti bahwa perdaban masyarakat Kebumen pada saat itu luar biasa dari sisi pengetahuan. Beberapa peradaban yang dibangun pada saat itu, Kebumen menjadi salah satu tempat pendidikan yang membawa pesan moral dan nilai-nilai dalam ilmu agama maupun ilmu-ilmu alam berkaitan dengan masalah-masalah pertanian berupa penanggalan dalam budaya jawa.

\section{PENUTUP}

\section{Kesimpulan}

Acara budaya dapat memainkan peran penting dalam pemasaran destinasi dan memiliki tujuan dalam mempengaruhi tujuan destinasi. Penelitian ini fokus untuk melihat seberapa besar acara budaya dapat menghasilkan kunjungan yang lebih bagi kalangan masyarakat yang lebih luas. Penelitian ini melihat dari mengidentifikasikan acara-acara budaya yang ada dilakukan pada dua aspek, yaitu pentas seni dan karnaval, dimana keduanya sering diadakan secara rutin oleh masyarakat. Ada enam peristiwa budaya dari pentas seni budaya, dan 4 peristiwa karnaval budaya yang penting untuk dianalisis. Peristiwa ini didasarkan pada tingkat regional dan yang memiliki ciri khas sebagai faktor pemicu adanya kunjungan. Hasil menunjukkan bahwa peristiwa budaya tersebut ternyata baru berorientasi untuk menarik kunjungan masyarakat yang kecil, yaitu yang berada pada sekitar penyelenggaraan tersebut, dan tidak ada dibangun pada penyelenggaraan yang besar di kabupaten Kebumen. Disamping itu juga kegiatan acara budaya tersebut, berlangsung satu kali dan periodik dalam satu tahun. Acara budaya ini belum mendapat respon menarik dari pengunjung dari luar kabupaten Kebumen, sehingga keinginan kunjungan bagi masyarakat di luar kabupaten Kebumen belum banyak. Oleh karena itu untuk menarik 
kunjungan dan tujuan kunjungan untuk tempat tinggal, bekerja, dan berinvestasi masih belum mampu memberikan dampak pendapatan di daerah ini.

\section{Saran}

Upaya yang perlu dilakukan pada penelitian ini adalah dengan mengidentifikasi alat-alat promosi dalam membangun komunikasi pemasaran budaya, untuk membuat pengunjung tertarik dan ikut merasakan bahwa dirinya merasa ikut menjadi bagian budaya tersebut dan pada akhirnya mau berkunjung atau mau tinggal diwilayah tersebut, dan berinvestasi ketika melihat potensi ekonomi yang didapat di wilayah tersebut. Sehingga rekomendasi penulis dalam peneltian ini adalah membangun dan mengintegrasikan budaya, dan stakeholder yang lain dalam membuat acara budaya agar tidak berjalan sendiri-sendiri terutama pada acara karnaval budaya melalui tema yang khusus. Hal ini adalah untuk menciptakan efisiensi biaya dan efektivitas dalam rangkaian acara budaya tersebut.

\section{DAFTAR PUSTAKA}

Andereck, Kathleen L., and Linda L. Caldwell. 1993. The Influence of Tourists' Characteristics on Ratings of Information Sources for an Attraction. Strategic Management Journal. 22:493-520.

Asunción Beerli, Josefa D. Martín, Agustín Quintana. (2004). "A model of customer loyalty in the retail banking market", European Journal of Marketing, Vol. 38 Issue: 1/2, pp.253-275

Baker MJ, Cameron E. (2008). Critical Success Factor in Destination Marketing. Tourism and Hospitality Research 8(2): 79-97.

Breen, H., Bull, A., Walo, M. (2001). A Comparison of survey methods to estimate visitor expenditure at a local event. Tourism Management, 22, pp. 473-479.

Buhalis, D. (2000). Marketing the competitive destination of the future. Tourism Management, 21, pp. 97-116.

Cassirer, Ernst. (1990). Manusia dan kebudayaan: sebuah esei tentang manusia. Terjemahan: Alois A Nugroho. Jakarta: Anggota IKAPI.

Cozmiuc, Cornelia. (2011). - City Branding - just a compilation of marketable assets?". Vol. XIV.

Dodds, R., Joppe, M. (2001). Promoting urban green tourism: the development of the other map of Toronto. Journal of Vacation Marketing, Vol. 7, No. 3, pp.261-3.

Fennell, D. (1996). A tourist space-time budget in the Shetland Islands. Annals of Tourism Research, 23, pp. 811-829. 
Framke, W. (2002). The Destination as a Concept: A Discussion of the Businessrelated Perspective versus the Sociocultural Approach in Tourism Theory. Scandinavian Journal of Hospitality and Tourism, Vol. 2, No. 2, pp. 92-108.

Gartner, W. (1994). Image Formation Process , Journal of Travel \& Tourism Marketing 2 (2-3):191-216

Getz, D. (2008). Event tourism: Definition, evolution, and reseach. Tourism Management, 29, pp. 402-427.

Green, B. C. (2003). Marketing the Host City: Analysing Exposure Generated By a Sport Event. International Journal of Sports Marketing and Sponsorhip, Dec/Jan, pp. 335-353.

Guba, Egon. (1990). The Paradigm Dialog. London : Sage Publications

Gummesson, E. (1999). Total Relationship Marketing. Butterworth-Heinemann, $281 \mathrm{p}$.

Hamidi (2010). Metode penelitian kualitatif: pendekatan praktis penulisan proposal dan laporan penelitian, Malang: UMM Press.

Hede, A. (2005). Sports-events, tourism and destination marketing strategies: an Australian case study of Athens 2004 and its media telecast. Journal of Sport Tourism, 10 (3), pp. 187-200.

Kaplanidou, K., Vogt, C. (2007). The Interrelationship between Sport Event and Destination Image and Sport Tourists' Behaviours. Journal of Sport \& Tourism, Vol. 12, No. 3-4, pp. 183-206.

Karavatzis, M. (2005). Place Branding: A Review of Trends and Conceptual Models. The Marketing Review, 5, pp. 329-342.

Kotler, P., Haider D. H., Rein, I. (1993). Marketing Places. Attracting Investment, Industry, and Tourism to Cities, States, and Nations. The Free Press, New York.

Kotler, P., Asplund, C., Rein, I., Heider, D. (1999). Marketing Places Europe: Attracting Investments, Industries, Residents and Visitors to European Cities, Communities, Regions and Nations. London, Pearson Education Ltd.

Kuhn, Thomas S. (1970). The Structure of Scientific Revolutions. Chicago and London: University of Chicago Press.

Lichrou, M., O’Malley, L., Patterson M. (2008). Place-product or place narrative(s)? Perspectives in the Marketing of Tourism Destinations. Journal of Strategic Marketing, Vol. 16, No. 1, pp. 27-39.

Macaryus, Sudartomo. (2008). Pembelajaran Seni di Masyarakat Sebuah Pengalaman. Makalah Disampaikan Pada Konverensi Internasional Kebudayaan Jawa pada tgl. 20-25 Oktober 2008 di Universitas Muhammadiyah Purwokerto. 
May Chiun Lo, Abang Azlan Mohamad, Peter Songan, Alvin Yeo, (2012) "Repositioning strategy in the ecotourism industry: a case of Bario", Business Strategy Series, Vol. 13 Issue: 1, pp.41-46

McCartney, G. J. (2005). Hosting a recurring mega-event: visitor raison d'e^tre. Journal of Sport Tourism, 10(2), pp. 113-128.

Moleong, L. J. (2010). Metodologi Penelitian Kualitatif, Bandung: Remaja Rosdakarya. Offset. (2007) Metodologi Penelitian Kualitatif, Bandung: Remaja Rosdakarya. Offset.

Morgan, R. M., Hunt, S. D. (1995). The Commitment - Trust Theory of Relationship marketing. Journal of Marketing, Vol. 58, Issue 3, pp. 2039.

Morgan, N.J., \& Pritchard, A. (1998). Tourism promotion and power: Creating images, creating identities. Chichester: Wiley. Annals of Tourism Research. 21(4), 756-779.

Mudrajad Kuncoro, (2005). Strategi Bagaimana Meraih Keunggulan Kompetitif. Jakarta: Erlangga, hlm. 86.

Rainisto, S. K. (2003). Success Factors of Place Marketing: a Study of Place Marketing Practices in Northern Europe and The United States, Helsinki: University of Technology.

Richards, G., Wilson, J. (2004). The Impact of Cultural Events on City Image: Rotterdam, Cultural Capital of Europe 2001. Urban Studies, Vol.41, No 10, pp. 1931-1951.

Rosenberg, L., Czepiel, J. A. (1984). A Marketing Approach to Customer Retention. Journal of Consumer Marketing, Vol. 1, pp. 45-51.

Skinner, H. (2008). The emergence and development of place marketing's confused identity. Journal of Marketing Management, Vol. 24, No. 9-10, pp.915-928.

Sugiono. (2005). Metode Penelitian Administrasi, Bandung: Alpabeta.

Wibawanto, S. (2015). Pendekatan konseptual Place Marketing dan Place Branding Dalam Destination Branding. Jurnal Fokus Bisnis, 14(18), 4246.

Woodside, A. G., and S. Lysonski. (1989). A General Model of Traveler Destination Choice. Journal of Travel Research. 27:8-14.

Wood, E. H. (2005). Measuring the economic and social impacts of local authority events. International Journal of Public Sector Management, Vol. 18, No. 1, pp. 37-53. 
Jurnal Manajemen dan Bisnis MEDIA EKONOMI, Volume XVIII, No. 2 Juli 2018 